\title{
A Case of Acute Idiopathic Non-specific Pneumonia with Dramatic Response to Treatment
}

\section{Tedaviye Dramatik Yanıt Veren Akut Idyopatik Nonspesifik Pnömoni Olgusu}

Gulsah Gunluoglu', Fatma Esra Günaydın², Halide Nur Urer³, Nurdan Kalkan', Nurdan Şimşek Veske', Sedat Altın'

\section{Abstract}

Non-specific interstitial pneumonia (NSIP) is a form of idiopathic interstitial pneumonia with a specific histological pattern involving varying degrees of alveolar wall inflammation or fibrosis, and with a temporal uniformity of lesions. The organized component can be found at different degrees, and the presence of a histologically organized component does not exclude a diagnosis of NSIP. Acute respiratory failure is rare in NSIP. A female patient who presented to our clinic with radiological findings of widespread consolidation and acute respiratory failure was diagnosed with NSIP with organized pneumonia through a surgical lung biopsy. The patient responded rapidly to steroid therapy, and the clinical findings improved dramatically. We present our case in order to emphasize the importance of treatment in the event of respiratory failure in idiopathic NSIP with organized pneumonia, and recommend rapid diagnosis and treatment.

Key words: NSIP, interstitial, acute respiratory failure.

\section{Özet}

Nonspesifik interstisyel pnömoni (NSiP), idiopatik interstisiyel pnömonilerin bir formudur. Spesifik histolojik paternini, değişken derecelerde alveolar duvar inflamasyonu veya fibrozis eşlik eden temporal uniform lezyonlar oluşturur. Organize komponent değişik derecelerde bulunabilir ve histolojik olarak organize komponentin varlığı NSiP tanısını dışlatmaz. Akut solunum yetmezliği NSiP'te nadir görülür. Radyolojik olarak yaygın konsolidasyon bulguları ve akut solunum yetmezliği tablosunda kliniğimize başvuran kadın hastaya, cerrahi akciğer biyopsisi yapılmış ve organize pnömoni komponentli NSiP tanısı konmuştur. Steroid tedavisine hızlı cevap gözlenmiş ve klinik bulgular dramatik olarak düzelmiştir. Organize pnömoni komponentili idiopatik NSIP olgularının solunum yetmezliği ile başvurabileceklerini ve hızlı tanı ve tedavinin bu hastalardaki önemini vurgulamak amaclyla olgumuzu sunuyoruz.

Anahtar Sözcükler: NSIP, interstisyel, akut solunum yetmezliği.

\footnotetext{
'Department of Pulmonary Disease, Health Sciences University, Yedikule Chest Diseases and Chest Surgery Training and Research Hospital, İstanbul, Turkey

'Sağlık Bilimleri Üniversitesi, Yedikule Göğüs Hastalıkları ve Göğüs Cerrahisi Eğitim ve Araştırma Hastanesi, Göğüs Hastalıkları Istanbul

2Department of Pulmonary Disease, Uludağ University Medical Facul- ${ }^{2}$ Uludağ Üniversitesi Tıp Fakültesi, Göğ üs Hastalıkları Ana ty, Division of Allergy and Clinical Immunology, Bursa, Turkey ${ }^{3}$ Department of Pathology, Health Sciences University, Bilim Dalı, Alerii ve Immünoloji Bilim Dalı, Bursa ${ }^{3}$ Sağlık Bilimleri Üniversitesi, Yedikule Göğüs Hastalıkları ve Yedikule Chest Diseases and Chest Surgery Training and Research Hospital, İstanbul, Turkey

Göğüs Cerrahisi Eğitim ve Araştırma Hastanesi, Patoloji, İstanbul
}

Submitted (Başvuru tarihi): 28.02.2019 Accepted (Kabul tarihi): 31.05 .2019

Correspondence (iletişim): Fatma Esra Günaydın, Department of Pulmonary Disease,

Uludağ University Medical Faculty, Division of Allergy and Clinical Immunology, Bursa, Turkey

e-mail: fatmaesragunaydin@gmail.com 
Non-specific interstitial pneumonia (NSIP) is a type of idiopathic interstitial pneumonia (IIP) that effects predominantly female never-smokers. The prevalence of NSIP is 1-10 in 100,000 (1). NSIP can occur as an idiopathic condition, or secondary to connective vascular disease, hypersensitivity pneumonia or drug toxicity.

Clinical manifestations are atypical for cryptogenic OP (COP) and idiopathic NSIP, and patients have also been identified with a rapid progressive presentation of interstitial pneumonia $(2,3)$. Although the presence of an organized pneumonia component in patients with histopathologically diagnosed NSIP has not been seen in a study in response to treatment, it has been reported that the clinical picture of such patients is more severe (4).

Most patients with idiopathic NSIP have a good prognosis, with a five-year predicted mortality rate of below $18 \%$ (3). It has been shown that the shorter duration of symptoms in patients with NSIP is higher in response to treatment. Corticosteroid and/or immunosuppressive are considered the optimum treatment $(3,5)$. In the present study, a patient who presented with acute respiratory failure and who was diagnosed histopathologically with organized pneumonia-treated NSIP responded dramatically to treatment.

\section{CASE}

A 45-year-old female patient who had been admitted to an outside clinic with sudden onset dyspnea 15 days previously was hospitalized with a diagnosis of pneumonia. The patient had no complaint prior to admission. She had received IV ceftriaxone (2gr/day) in the outside clinic. Despite being treated for pneumonia, no clinical radiological response was identified, leading her to be referred to our center for further examination and treatment. Upon physical examination, the patient was found to be tachypneic and had auxiliary respiratory muscle use. Breathlessness increased even from movement within the bed. Her vital signs were as follows: blood pressure 120/70 $\mathrm{mm} \mathrm{Hg}$, heart rate of $80 \mathrm{bpm}$, respiratory rate $32 / \mathrm{min}$, and oxygen saturation of $85 \%$ in room air $194 \%$ with nasal $2 \mathrm{~L} / \min \mathrm{O}_{2}$ ). An examination of the respiratory system revealed bilaterally late inspiratory coarse crackles in the middle and lower areas.

Arterial blood gas obtained while the patient was using a nasal cannula with an oxygen flow of $2 \mathrm{~L} /$ minute and showed $\mathrm{pH}:$ 7.51, $\mathrm{pCO}_{2}: 34.6 \mathrm{mmHg}, \mathrm{pO}_{2}$ 55.5: $\mathrm{mm}$ $\mathrm{Hg}, \mathrm{BE}: 4 \mathrm{mmol} / \mathrm{L}-7, \mathrm{HCO}_{3}: 27 \mathrm{mmol} / \mathrm{L}, \mathrm{O}_{2}$ sat: 91.8\%. A complete blood count $(\mathrm{CBC})$ showed white blood cells (WBC) of 17,590/uL, neutrophil count of $15,010 / \mathrm{IU}(85 \%)$, eosinophil count of $0(0 \%), \mathrm{Hb}$ of
$10.8 \mathrm{~g} / \mathrm{dL}$ and platelet count of 428.000/IL. The sedimentation rate was $60 \mathrm{~mm} / \mathrm{h}, \mathrm{CRP}$ value was $17.5 \mathrm{mg} /$ $\mathrm{L}$, procalcitonin value was $0.110 \mathrm{ng} / \mathrm{ml}$. Serum electrolyte, renal function and liver function tests were normal. Serum Anti-HBS, HbS Ag, Anti HCV, Anti-HIV and HIV RNA were found to be negative. Imipenem $500 \mathrm{mg} 4 \times 1$ IV, trimethoprim sulfamethoxazole $400 \mathrm{mg} / 80 \mathrm{mg} 3 \times 2$ IV were given empirically. A routine sputum culture grew only normal oral flora, and three consecutive negative sputum acid fast bacillus (AFB) smear examinations were conducted. A nasal swab viral panel was evaluated as negative. A posteroanterior chest $\mathrm{X}$-ray revealed nonhomogeneous infiltrations in the bilateral middle and lower zones (Figure 1). A thorax CT scan revealed the presence of reticular densities and ground glass opacity with an irregular shape bilaterally in the middle and lower zones, and rare interseptal thickenings in the basal zones (Figure 2).

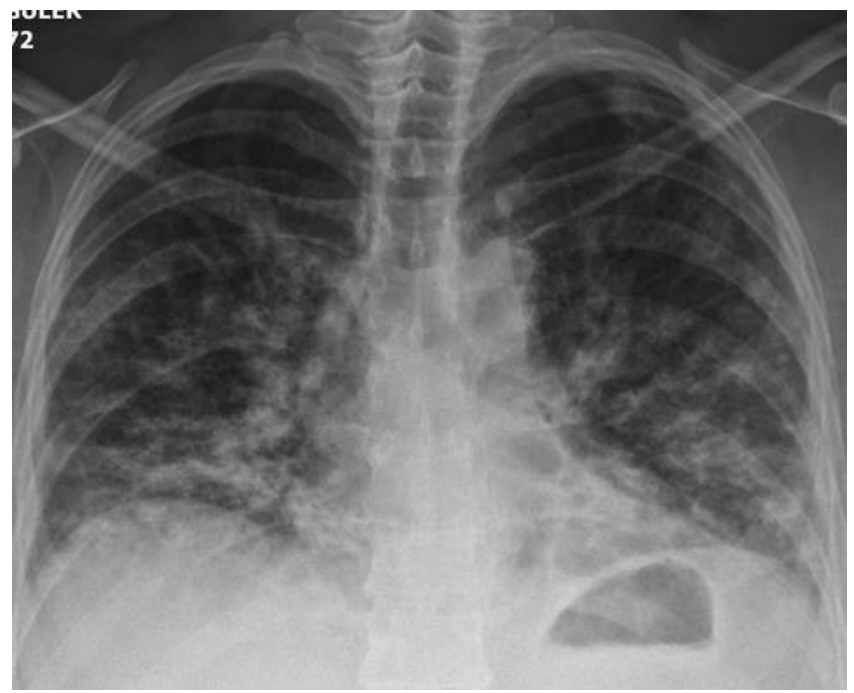

Figure 1: Chest radiograph at the time of admission showing nonhomogeneous infiltrations in bilateral middle and lower zones

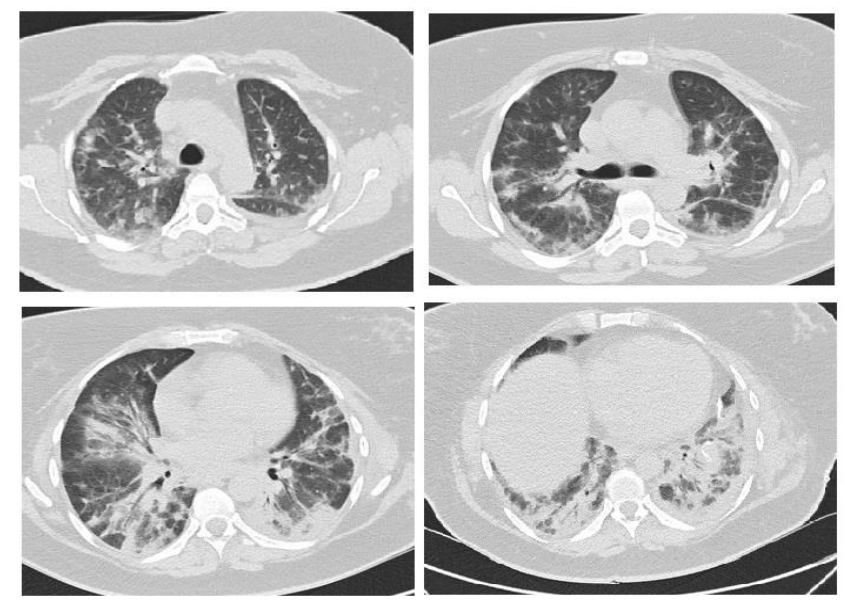

Figure 2: Chest-CT showing reticular densities and ground glass opacity with irregular shape in the middle and lower zones bilaterally 
A fiber optic bronchoscopy was performed under local anesthesia. Both bronchial systems were normal. Bronchial lavage was taken from the middle and lower bronchus, and the bronchoscopy was terminated after taking the bronchial lavage due to severe desaturation. The bronchial lavage non-specific culture, AFB examination, tuberculosis $P C R$, fungal cultures were negative, and no malign cells were found.

Despite treatment, the patient suffered worse clinical radiological outcomes. After the 10th day of hospitalization, CPAP treatment was started due to tachypnea under 10 L/minute oxygen support. Video-assisted thoracoscopic surgery (VATS) was performed on the left lower lobe and upper lobe wedge biopsies were taken for diagnosis.

In the postoperative period, the patient underwent intermittent CPAP treatment, and no surgical complications were observed in the early and late period. The pathology result of the surgical biopsy identified nonspecific interstitial pneumonia of a mixed type with an organized pneumonia component (Figure 3). No pathology was detected in the rheumatologic examination of the patient, and the collagen tissue markers (ANA, RF, anti CCP, anti dsDNA, anti RNP, anti Sm, anti SS-A, anti SS-B, anti Scl-70, anti Jo-1) and ANCA profile (C-ANCA, P-ANCA) were negative. She had no history of drug use of occupational exposure. She had no muscle weakness, muscle pain, back and low back pain, skin rashes, nail changes, skin stiffness, tear reduction, dry mouth, redness of the eyes or long-term high fever. For this reason, idiopathic NSIP was accepted, and a $1 \mathrm{mg} / \mathrm{kg}$ dose of methylprednisolone treatment and azathioprine $150 \mathrm{mg} /$ day immunosuppressive treatment was started simultaneously. With the initiation of treatment, dramatic improvement was observed in the patient's clinical findings and oxygenation.

After the 15th day of the treatment, the need for oxygen dissipated, even under effort. The dose of steroids was decreased and the patient was followed-up. The patient is currently being treated with methylprednisolone $12 \mathrm{mg} /$ day and azothioprine $150 \mathrm{mg} /$ day. Radiologically, the consolidation areas have regressed, whereas in the basals, fibrosis and traction bronchiectasis are present in the subpleural space (Figure 4). Force vital capacity in the pulmonary function test (FVC) is 1.81 Lt 52\%, DLCO: $3.21 \mathrm{ML} 36 \%$. The patient has walked $440 \mathrm{~m}$ in 6 minutes, with no desaturation noted after exercise.
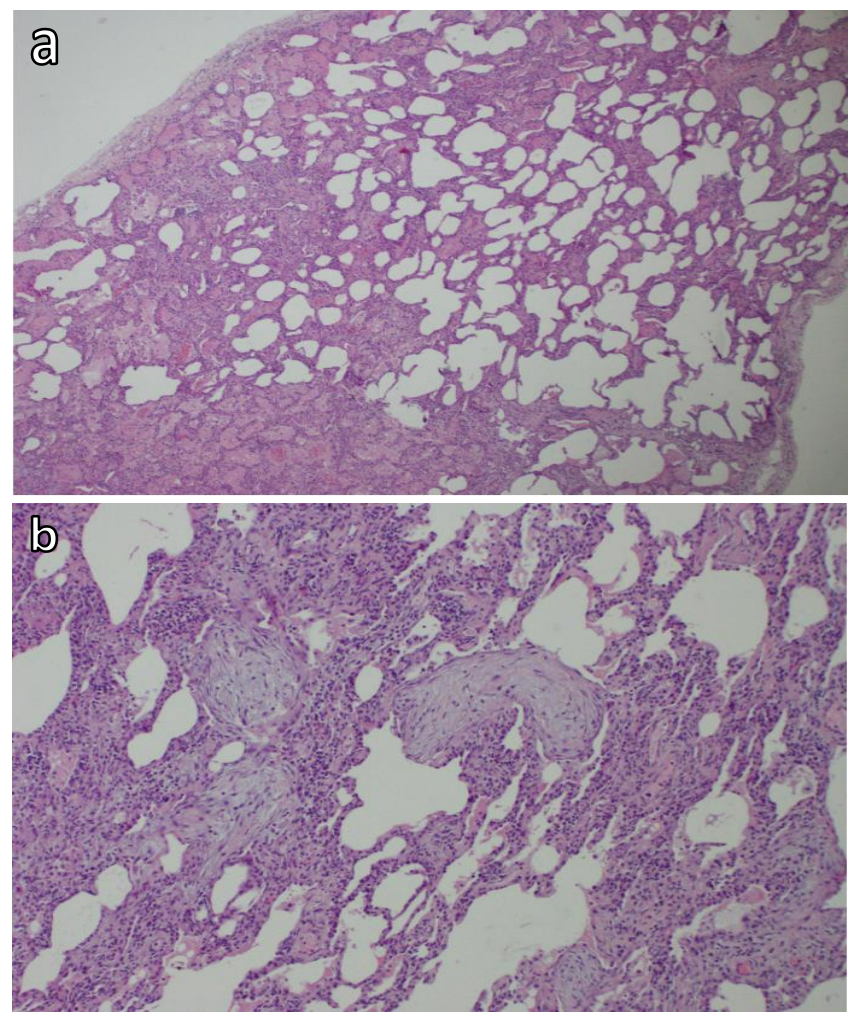

Figure $3 a$ and $b$ : Interstitial diffuse involvement (a), interstitial pneumonia associated intraalveolar fibromyxoid plugs (b)

\section{DISCUSSION}

NSIP is categorized as a special clinicopathological form of chronic fibrotic idiopathic interstitial pneumonia, although an NSIP pattern may be rarer in patients with acute and subacute clinical conditions. NSIP patients with an acute or subacute clinical course have a histological organized pneumonia pattern in addition to an NSIP pattern (6). Whether such cases can still be diagnosed as NSIP or OP, or whether they should be categorized as another disease entity (e.g. variant of organizing pneumonia with supervening fibrosis) or referred to only as unclassifiable IIP (7) is not apparent. In rapidly progressive interstitial pneumonia, the differentiation of ' $O P$ or $N S I P$ ' from 'DAD or DAD+UIP' is reported to be important, in that the former has better survival than the latter (8.)

In the present case, no clinical symptoms were present until a short time before the application, and increasing symptoms of acute respiratory failure occurred within days. Acute and subacute idiopathic interstitial pneumonia radiologically, as in our patient, HRCT was shown to have a bilateral consolidation infiltration image that initially leads patients to be evaluated with pneumonia. 

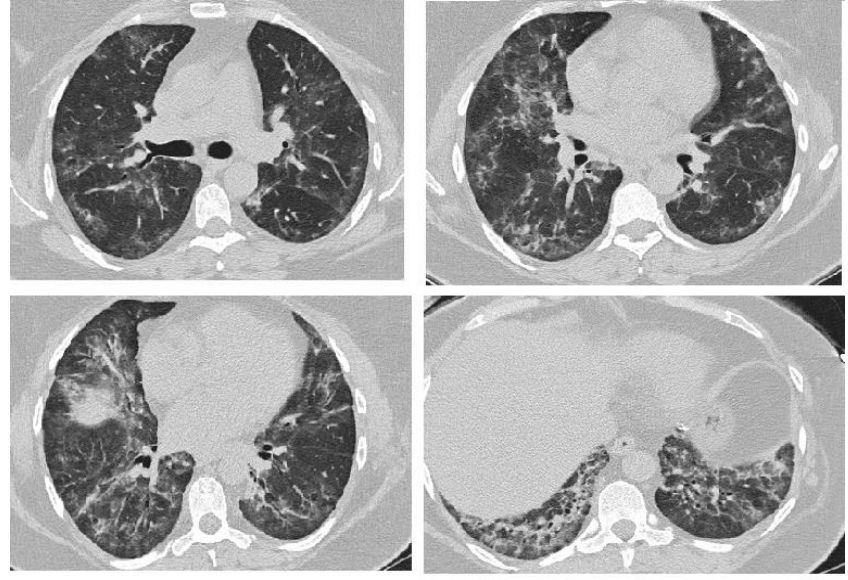

Figure 4: Chest-CT at the time of 1th month of treatment showing, fibrosis and traction bronchiectasis in the subpleural space

NSIP may also appear as a component of other diseases, such as connective tissue disease, hypersensitivity pneumonitis and organized pneumonia (1). The presence of organized pneumonia in a histopathology may cause confusion in the diagnosis of NSIP.

The organized component is observed in both the cellular and fibrosing / mix types at different rates. That said, the pathological cellular type NSIP has been found to be more intense, especially in the composition of organized pneumonia (9). The authors emphasize that the presence of organized pneumonia should not exclude NSIP if clinically and radiologically appropriate. OP / NSIP pattern has been significantly associated with connective tissue disease $(4,9)$.

In a series of 136 patients with biopsy-proven NSIP cases, the best prognosis was observed in the NSIP / OP subgroup of the histological subtypes (4). NSIP has a reasonably good prognosis when treated with steroids. Travis et al. (10) found that patients with cellular NSIP had better 5-year and 10-year survival rates than those with $\mathrm{fi}$ brosing NSIP. Although the prognosis of fibrotic type NSIP is better than IPF, the 5 -year mortality rate is estimated to be $17.7 \%$ (3). It is important to distinguish between NSIP and other idiopathic interstitial pneumonias. It has been observed that early treatment with corticosteroid and / or immunosuppressive improves the prognosis, although the patient had no obvious symptoms.

Respiratory function parameters improved or stabilized in $80 \%$ of the treated patients (11). A recent cohort study identified a short duration of pulmonary symptoms as a good indicator in response to treatment (9).

NSIP may have an acute or subacute presentation, or acute exacerbation may occur in a previously subclinical or unrecognized NSIP (12). NSIP leads to acute respiratory failure, and should be considered especially in patients who present with acute respiratory distress and with radiological bilateral widespread consolidation and ground glass areas and did not respond clinically and radiologically to antibiotic treatment. A combination of interstitial changes and consolidated areas in a high-resolution chest tomography should suggest a histopathologically organized pneumonia pattern. In such rare cases, a dramatic response to early diagnosis and treatment can be obtained.

\section{CONFLICTS OF INTEREST}

None declared.

\section{AUTHOR CONTRIBUTIONS}

Concept - G.G., F.E.G., H.N.U., N.K., N.S.V., S.A.; Planning and Design - G.G., F.E.G., H.N.U., N.K., N.S..V., S.A.; Supervision - G.G., F.E.G., H.N.U., N.K., N.S..V., S.A.; Funding - G.G., S.A.; Materials - G.G., F.E.G., S.A.; Data Collection and/or Processing - G.G., F.E.G., H.N.U.; Analysis and/or Interpretation - G.G., F.E.G.; Literature Review - G.G., F.E.G.; Writing - G.G., F.E.G., H.N.U.; Critical Review - G.G., S.A.

\section{YAZAR KATKILARI}

Fikir - G.G., F.E.G., H.N.U., N.K., N.Ş.V., S.A.; Tasarım ve Dizayn - G.G., F.E.G., H.N.U., N.K., N.S.V., S.A.; Denetleme - G.G., F.E.G., H.N.U., N.K., N.S.V., S.A.; Kaynaklar - G.G., S.A.; Malzemeler - G.G., F.E.G., S.A.; Veri Toplama ve/veya İşleme - G.G., F.E.G., H.N.U.; Analiz ve/veya Yorum - G.G., F.E.G.; Literatür Taraması - G.G., F.E.G.; Yazıyı Yazan - G.G., F.E.G., H.N.U.; Eleştirel İnceleme - G.G., S.A.

\section{REFERENCES}

1. Flaherty KR, Martinez FJ. Nonspecific interstitial pneumoniae. Semin Respir Crit Care Med 2006; 27:652-8. [CrossRef]

2. ATS/ERS Committee on Idiopathic Interstitial Pneumonias. American Thoracic Society/European Respiratory Society international multidisciplinary consensus classification of the idiopathic interstitial pneumonias. Am J Respir Crit Care Med 2002; 165:277-304. [CrossRef]

3. Travis WD, Hunninghake G, King TE, Lynch DA, Colby TV, Galvin JR, et al. Idiopathic nonspecific interstitial pneumonia: report of an American Thoracic Society project. Am J Respir Crit Care Med 2008; 177:1338-47. [CrossRef]

4. Kambouchner M, Levy P, Nicholson AG, Schubel K, Magois $E$, Feuillet $S$, et al. Prognostic relevance of histologi- 
cal variants in nonspecific interstitial pneumonia. Histopathology 2014; 65:549-60. [CrossRef]

5. Belloli EA, Beckford R, Hadley R, Flaherty KR. Idiopathic non-specific interstitial pneumonia. Respirology 2016; 21:259-68. [CrossRef]

6. Beardsley B, Rassl D. Fibrosing organising pneumonia. J Clin Pathol 2013; 66:875-81. [CrossRef]

7. Travis WD, Costabel U, Hansell DM, King TE Jr, Lynch DA, Nicholson AG, et al. An official American Thoracic Society/European Respiratory Society statement: update of the international multidisciplinary classification of the idiopathic interstitial pneumonias. Am J Respir Crit Care Med 2013; 188:733-48. [CrossRef]

8. Kondoh $Y$, Taniguchi $H$, Kataoka K, Kato K, Suzuki R, Ogura $T$, et al. Prognostic factors in rapidly progressive interstitial pneumonia. Respirology 2010; 15:257-64. [CrossRef]
9. Huo Z, Li J, Li S, Zhang H, Jin Z, Pang J, et al. Organizing pneumonia components in non-specific interstitial pneumonia (NSIP): a clinicopathological study of 33 NSIP cases. Histopathology 2016; 68:347-55. [CrossRef]

10. Travis WD, Matsui K, Moss J, Ferrans VJ. Idiopathic nonspecific interstitial pneumonia: prognostic significance of cellular and fibrosing patterns: survival comparison with usual interstitial pneumonia and desquamative interstitial pneumonia. Am J Surg Pathol 2000; 24:19-33. [CrossRef]

11. Park IN, Jegal Y, Kim DS, Do KH, Yoo B, Shim TS, et al. Clinical course and lung function change of idiopathic nonspecific interstitial pneumonia. Eur Respir J 2009; 33:68-76. [CrossRef]

12. Taniguchi $H$, Kondoh $Y$. Acute and subacute idiopathic interstitial pneumonias. Respirology 2016; 21:810-20. [CrossRef] 